\title{
Gastroduodenal artery aneurysm
}

\author{
Khalid Akbari, ${ }^{1,2}$ Claire Wood, ${ }^{3}$ Nafees Ahmad, ${ }^{4}$ Michael Yapanis ${ }^{4}$
}

1 Department of General Surgery, Forth Valley Hospital, Stirlingshire, UK

${ }^{2}$ Department of General Surgery, Royal Berkshire Hospital, Reading, Berkshire, UK

${ }^{3}$ Forth Valley Hospital, Stirlingshire, UK

${ }^{4}$ Department of Vascular Surgery, Forth Valley Hospital, Stirlingshire, UK

\section{Correspondence to}

Dr Khalid Akbari, docakbari@ gmail.com

Accepted 28 May 2014
CrossMark

To cite: Akbari $\mathrm{K}$, Wood $\mathrm{C}$, Ahmad N, et al. BMJ Case Rep Published online: [please include Day Month Year] doi:10.1136/bcr-2014203939

\section{DESCRIPTION}

An 88-year-old female smoker presented with a 5 -week history of constant epigastric pain. On examination, she was haemodynamically stable, tender in the epigastrium and had a palpable pulsation in the right upper quadrant. Her full blood count, liver function tests and amylase were normal. Abdominal ultrasound scan showed a normal gallbladder, biliary tree and abdominal aorta. However, an aneurysm adjacent to the left lobe of the liver was visualised. Contrast CT scan confirmed this to be a non-ruptured gastroduodenal artery aneurysm (figure 1), measuring $30 \mathrm{~mm}$ in diameter (figure 2).

Like all aneurysms, those of the visceral artery can be true or false; the latter arise secondary to inflammation as seen in acute pancreatitis and following procedures such as cholecystectomy. Aneurysms of the visceral arteries are uncommon, and of these, gastroduodenal artery (GDA) aneurysms account for only $1.5 \%$. The vast majority of reported GDA aneurysms are false; true aneurysms are a rare finding. ${ }^{12}$

Non-ruptured GDA aneurysms are usually asymptomatic; ruptured GDA aneurysms present with shock. Complications vary from gastric outlet obstruction to haemobilia. Gold standard investigation is visceral angiography, which also allows radiological embolisation. CT scan helps to

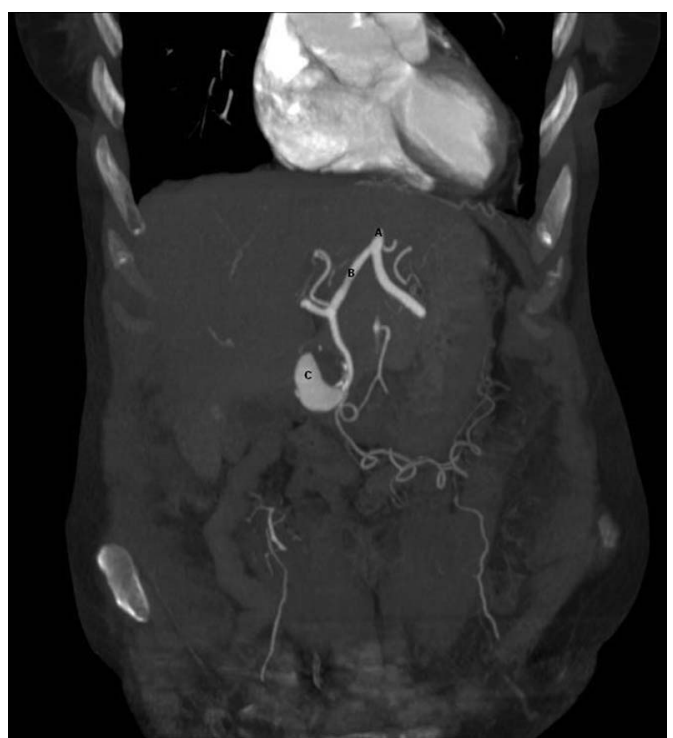

Figure 1 Sagittal section of CT angiogram showing coeliac trunk (A), common hepatic artery (B) and an aneurysmal gastroduodenal artery (C).

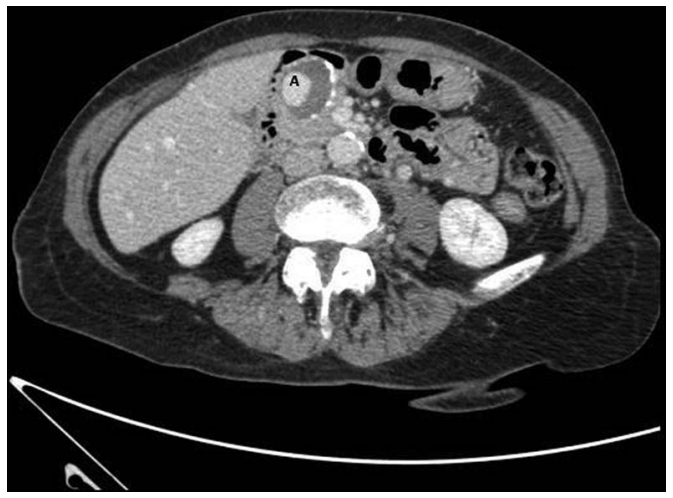

Figure 2 Coronal section of CT showing aneurysmal gastroduodenal artery $(A)$.

delineate vascular anatomy in relation to surrounding structures when planning surgical repair, as this is the mainstay of treatment. Embolisation and stenting are possible endovascular options in uncomplicated stable aneurysms. ${ }^{1}$ Our patient is listed for an elective radiological embolisation.

\section{Learning points}

Visceral artery aneurysms of the gastroduodenal artery are very rare.

- Presentation is vague but rupture of such aneurysms is life threatening.

- Once identified, an early vascular input and intervention are important.

Contributors All the authors contributed equally to review of the images and critique of the text as well as follow-up of the patient information after her initial presentation and reviewing the revised version of the report.

\section{Competing interests None.}

Patient consent Obtained.

Provenance and peer review Not commissioned; externally peer reviewed.

\section{REFERENCES}

1 Nicholas H, Samer H, Rafik A, et al. Gastroduodenal artery aneurysm, diagnosis, clinical presentation and management: a concise review. Ann Surg Innov Res 2013;7(1):4.

2 Harris K, Chalhoub M, Koirala A. Gastroduodenal artery aneurysm rupture in hospitalized patients: an overlooked diagnosis. World J Gastrointest Surg 2010;2:291-4. 


\section{Images in...}

Copyright 2014 BMJ Publishing Group. All rights reserved. For permission to reuse any of this content visit http://group.bmj.com/group/rights-licensing/permissions.

BMJ Case Report Fellows may re-use this article for personal use and teaching without any further permission.

Become a Fellow of BMJ Case Reports today and you can:

- Submit as many cases as you like

- Enjoy fast sympathetic peer review and rapid publication of accepted articles

- Access all the published articles

- Re-use any of the published material for personal use and teaching without further permission

For information on Institutional Fellowships contact consortiasales@bmjgroup.com

Visit casereports.bmj.com for more articles like this and to become a Fellow 